\title{
Pengaruh Kondisi Sosial Ekonomi Petani Karet Terhadap Pendapatan Petani Karet Di Kabupaten Muaro Jambi (Studi Kasus di Kecamatan Jambi Luar Kota)
}

\author{
oleh: \\ *) Rika Neldawati \\ **) Sekolah Tinggi IImu Ekonomi Muhammadiyah Jambi
}

\begin{abstract}
Abstrak
Di Kabupaten Muaro Jambi luas perkebunan komoditas karet sampai tahun 2009 mencapai 58.034 Ha atau sebesar 21,90 persen dari luas areal perkebunan karet di Provinsi Jambi, Hal ini menunjukkan besarnya potensi komoditas lurret untuk dikembangkan guna menopang perekonomian rakyat di Kabupaten Muaro Jambi. Dari sisi penyerapan tenaga kerja, maka usaha tani perkebunan karet ini mampu menyerap 14.911 rumah tangga petani karet. Namun kondisi sosial ekonominya masih sangat memprihatinkan. Hal ini tidak terlepas dari tingkat pendidikan yang rendah, sanitasi lingkungan yang kurang sehat, sarana dan prasarana sosial yang kurang memadai dan masih tertinggal. Dari sisi ekonomi pendapatan petani merupakan variabel yang berperan penting dalam meningkatkan kesejahteraan masyarakat. Variabel ini ditunjang oleh kondisi sosial masyarakat guna meningkatkan produktivitas petani yang ada di Kabupaten Muaro Jambi.
\end{abstract}

Kata Kunci : Tenaga Kerja, Pendapatan, Kesejahteraan, Produktivitas

\section{Latar Belakang}

Sejak awal pembangunan, peranan sektor pertanian dalam pembangunan di Indonesia, tidak perlu diragukan lagi. Pembangunan sektor pertanian diarahkan untuk meningkatkan produktivitas hasil pertanian guna memenuhi kebutuhan pangan masyarakat dan kebutuhan industri dalam negeri. Disamping itu juga meningkatkan eksport, meningkatkan pendapatan petani, memperluas kesempatan kerja serta mendorong kesempatan berusaha (Soekartawi, 2002 ).

Sebagaimana daerah lainnya di Indonesia, sebagian besar penduduk Provinsi Jambi, yaitu sebesar $61 \%$ berdomisili di daerah pedesaan dengan mata pencaharian utama pada sektor pertanian. Tidak dapat dipungkiri pula bahwa sebagian besar masyarakat masih hidup dibawah garis kemiskinan, yaitu sebesar $28,64 \%$. Kondisi ini bila tidak dapat diatasi akan menimbulkan ketimpangan yang besar dalam pembangunan, khususnya antara daerah pedesaan dan daerah perkotaan. Upaya-upaya mengurangi kerimpangan tersebut harus dilakukan, terutama terkait erat dengan program-program pembangunan daerah pedesaan dan pengintegrasiannya dengan pembangunan daerah perkotaan.

Provinsi Jambi merupakan salah satu daerah pertanian di Indonesia, komoditas pertani yang cukup banyak di usahakan petani dan memegang peranan penting di daerah Jambi adalah Karet, terutama sebagai salah satu komoditi unggulan ekspor daerah Jambi. Dari berbagai komoditas perkebunan, perkebunan karet memiliki lahan terluas di Provinsi Jambi. Sampai tahun 2009 luas tanaman perkebunan karet mencapai 621. $302 \mathrm{Ha}$ atau 
sebesar 47,94 persen dari luas areal perkebunan di Provinsi Jambi, Hal ini memungkinkan betapa besarnya potensi komoditas karet untuk dikembangkan guna menopang perekonomian rakyat.

Kabupaten Muaro Jambi sebagai salah satu daerah penghasil karet di Provinsi Jambi turut memberikan kontribusi terhadap perkembangan perkebunan karet di Provinsi Jambi. Hasil-hasil komoditas pertanian karet yang dihasilkan oleh Desa-Desa di kabupaten Muaro Jambi sudah dapat di jual ke daerah lainnya, bahkan untuk pasar ekspor.

Salah satu wilayah yang banyak terdapat tanaman karet di Kabupaten Muaro Jalnbi adalah Kecamatan Jambi Luar Kota. Dimana di daerah ini hampir setiap desa banyak penduduknya yang bekerja menjadi petani karet. Menurut catatan Kantor Camat Jambi Luar Kota, luas lahan pertanian karet di Kecamatan Jambi luar Kota adalah sebesar 11.665 ha. Dengan menyerap tenaga kerja dengan rumah tangga yang bekerja di perkebunan karet sebanyak 1368 rumah tangga. Mengingat potensi lahan yang cukup besar di Kecamatan Jambi luar Kota Kabupaten Muaro Jambi sangat besar, maka pemerintah Kabupaten dan Kecamatan hams terus melakukan pembinaan kepada petani karet di Kecamatan Jambi Luar Kota Kabupaten Muaro Jambi.

\section{Perumusan Masalah}

Berdasarkan latar belang penelitian, maka masalah yang akan diangkat dalam penelitian ini diajukan dalam pertanyaan berikut :

1. Bagairnana karakteritistik sosial ekonomi petani karet di Kecamatan Jambi Luar Kota Kabupaten Muaro Jambi?

2. Faktor-faktor apa saja yang mempengaruhi tingkat pendapatan petani karet di Kecamatan Jambi Luar Kota Kabupaten Muaro Jambi?

\section{Landasan Teoritis}

Pembangunan Sektor Pertanian dan Sub Sektor Perkebunan Ekonomi pembangunan (Develovment Economics) mulai berkembang dibelahan dunia Barat sejak perang dunia kedua berakhir. Menurut Arif (2000) tujuannya adalah untuk menganalisa apa yang disebut ekonomi negara-negara. berkembang. Oleh karena itu Prayitno dan Santoso (2002) secara. lebih khusus menekankan arti pembangunan ekonomi sebagai upaya yang dilakukan suatu negara dengan tujuan mengembangkan kegiatan ekonomi.

Pendapat sebelumnya juga sestaai dengan pendapatan Arsyad (2001) yang melihat bahwa ekonomi pembangunan adalah usaha-usaha pembangunan yang banyka dilakiikan negara-negara yang sedang berkembang pasca perang dunia ke II. Dalam pelaksanaannya banyak mengalami kegagalan dalam memecahkan masalah-masalah pembangunan, misalnya kemiskinan dan kepincangan distribusi pendapatan. Oleh karena itu konsep 
pembangunan tidak terlepas dari konsep ekonomi pembangunan sebagai sebuah disiplin ilmu yang bertujuan mencari solusi peningkatan kesejahteraan masyarakat.

Peningkatan kesejateraan masyarakat mutlak harus dilakukan, karenanya diperlukan kebijaksanaan pembangunan lintas sektoral pada berbagai aspek kehidupan masyarakat. Tidaklah mengeherankan bila Todaro (2002) mendefinisikan pembangunan sebagai suatu proses perubahan yang bersifat multi demensional yang mencakup perubahan terpenting dalam struktur sosial, sikapsikap rakyat dan lembaga-lembaga ekonomi dan juga akselerasi pertumbuhan ekonomi penguraugan kesenjangan dan pemberantasan kemiskinan absolut.

Pembangunan ekonomi secara nasional melibatkan berbagai instrunen dan lembaga yang mengikat seluruh kebijakan pembangunan secara nasional. Oleh karena itu kebijakan pembangunan nasional pada dasarnya berlaku secara universal dan kurang mempertimbangkan aspek potensi daerah. Dalam konteks inilah maka berkembang pembangunan ekonomi daerah. Menurut Arsyad (2001) Pembangunan ekonomi daerah adalah suatu proses dimana pemerintah daerah dan masyarakat mengelola sumberdayasumberdaya yang ada. Disamping itu juga membentuk suatu pola kemitraan antara pemerintah daerah dengan sektor swasta untuk menciptakan suatu lapangan kerja baru dan merangsang perkembangan kegiatan ekonomi (pertumbuhan ekonomi) dalam wilayah tersebut.

Masalah pokok dalam pembangunan daerah adalah terletak pada penekanan terhadap kebijakan-kebijakan pembangunan yang didasarkan pada kekhasan daerah yang bersangkutan (endogenous development) dengan menggunakan potensi sumberdaya manusia, kelembagaan, dan sumberdaya fisik secara lokal (daerah). Orientasi ini mengarahkan kita kepada pengambilan inisiatif-inisiatif yang berasal dari daerah tersebut dalam proses pembangunan untuk menciptakan kesempatan kerja baru dan merangsang peningkatan kegiatan ekonomi.

Sebagai daerah yang bertipologi pertanian maka idealnya kebijakan pmbangunan harus lebih berorientasi kepada pengembangan sektor pertanian sebagai leading sektor. Dillon (2004) mengungkapkan bahwa kehancuran ekonomi bangsa Indonesia pasca Orde Baru karena diabaikannya sektor pertanian dalam proses pembangunan. Padahal, sektor pertanian mempunyai 4 fungsi yang sangat fundamental bagi pembangunan suatu bangsa, yaitu: 1) Mencukupi pangan alam negeri 2) penyedia lapangan kerja dan berusaha 3) penyedia bahan baku untuk industri dan 4) sebagai penghasil devisa bagi negara. Lebih lanjut Adjid (2001) mengungkapkan bahwa peranan sektor dalam pembangunan ekonomi bangsa sangat penting karena. sebagian masyarakat dinegara-negara sedang berkembang menggantungkan harapan hidupnya pada sektor pertanian.

Pembagunan pertanian menurut Adjid (2001) pada dasamya adalah suatu rangkaian panjang dari perubahan atau peningkatan kapasitas, kualitas, profesionalitas, dan peningkatan roduktivitas tenaga kerja pertanian yang disertai dengan penataan dan 
pengembangan lingkungan fisik dan sosialnya sebagai manfestasi dari akumulasi dan aplikasi kemajuan ilmu pengetahuan dan teknologi.

Prinsip dasar pembangunan sektor pertanian merupakan salah satu misi yang terus diupayakan pemerintah. Ha1 ini terkait dengan banyaknya penduduk Indonesia yang tinggal di daerah pedesaaan dan menghilangkan kemiskinan penduduk. Oleh karena itu Mubyarto (2000) mengungkapkan bahwa masalah kemiskinan ini cukup pelik, sehingga berbagai usaha untuk menghilangkannya perlu dilakukan secara rapi dan terpadu mencakup usaha-usaha 1) meningkatkan dan memperluas produksi pertanian, 2) meningkatkan kesempatan kerja baik di dalam maupun di luar sektor pertanian, 3) mengurangi kemiskinan terutama yang mengakibatkan kekurangan gizi dan menciptakan lingkungan yang baik untuk memperlambat pertumbuhan penduduk.

Oleh karenanya strategi pembangunan sektor pertanian terutama di daerah pedesaan menurut Mubyarto (2000) Pertama: pembangunan pertanian didasarkan pada orientasi lembaga peningkatan kesempatan kerja. Kedua: meningkatkan dan membina lambaga pelayanan sosial khususnya pendidikan aan kesehatan dan Ketiga: memperkuat serta membina prasarana kelembagaan dan keahlian manajemen bagi penduduk desa.

Apabila tujuan utama pembangunan pertanian dan daerah pedesaan di negaranegara Dunia Ketiga termasuk Indonesia untuk memperbaiki taraf hidup masyarakat pedesaan melalui peningkatan pendapatan, total produksi dan produktivitas petani kecil, maka menurut Todarro (2002) pertama-tama pihak pemerintah negara-negara berkembang termasuk Indonesia harus melakukan identifikasi sumber-sumber pokok kemajuan pertanian dan kondisi-kondisi dasar yang sekiranya akan mempengaruhi keberhasilan pencapaian tujuan utama itu. Semua unsur yang penting tersebut jelas berkaitan satu sama lain sehingga membentuk suatu jalinan hubungan yang amat kompleks, akan tetapi untuk memudahkan pemahaman maka dapat dipisahkan menjadi dua komponen, yaitu :

1. Sumber-sumber kemajuan pertanian berskala kecil

a. Kemajuan teknologi dan inovasi

b. Kebijaksanaan ekonomi pemerintah yang tepat

c. Kelembagaan sosial yang menunjang.

2. Syarat umum bagi kemajuan pedesaan

a. Modernisasi struktur usaha tani dalam rangka memenuhi permintaan bahan pangan yang terus meningkat.

b. Penciptaan sistem penunjang yang efektif

c. Perubahan konsisi sosial pedesaan guna memperbaiki taraf hidup masyarakat pedesaan 


\section{Faktor Sosial Ekonomi dan Pendapatan Petani}

Usaha tani dalam konsep di atas mempunyai pengertian bahwa petani adalah mengorganisir faktor produksi untuk kemudian dilakukan aktivitas produksi dengan memanfaatkan potensi yang ada untuk menghasilkan produksi secara optimal. Pengertian usaha tani tidak hanya sebatas pada bercocok tanam tetapi lebih jauh berkaitan dengan kegiatan dibidang produksi peternakan, perkebunan dan perikanan. Oleh karena itu pada prinsipnya kegiatan produksi menempatkan petani sebagai pengorganisasi faktor produksi untuk menghasilkan output.

Pengertian pendapatan rumah tangga di atas mempunyai arti bahwa pendapatan terdiri dari pendapatan dalam bentuk uang dan barang yang memiliki nilai yang sama dengan uang. Namun demikian dalam konteks usaha tani penerimaan dapat berupa hasil panen dan dalam bentuk uang apabila telah dijual. Menurut Hernanto (2002 ) penerimaan usaha tani adalah penerimaan dari semua sumber usaha tani yang meliputi :

1. Jumlah penambahan inventaris

2. Nilai penjualan hasil

3. Harga pembelian dikurangi penyusutan.

Berdasukan konsep di atas usaha menambah faktor produksi dapat dikategorikan sebagai pendapatan petani. Namun pada pokoknya yang mempengaruhi pendapatan dari usaha tani adalah nilai penjualan hasil produksi petani. Hal ini sejalan dengan pendapat Wisnuaji (2002) pendapatan usaha tani adalah selisih antara penerimaan dan semua biaya. Jadi :

$$
\pi=\mathrm{TR}-\mathrm{TC}
$$

Dimana

$$
\begin{array}{ll}
\pi & =\text { Keuntungan } \\
\mathrm{TR} & =\text { Total Revenue } \\
\mathrm{TC} & =\text { Total Cost (total biaya) }
\end{array}
$$

Menurut Soekartawi (2005) penerimaan usaha tani adalah perkalian antara produksi yang diperoleh dengan harga jual. Secara matematis pernyataan ini dapat dituliskan sebagai berikut :

$\mathrm{TR}_{\mathrm{i}}=\mathrm{Y}_{\mathrm{i}}-\mathrm{P}_{\mathrm{Yi}}$

Di mana :

$\mathrm{TR}=$ Total Revenue (Penerimaan Total)

$\mathrm{Y}=$ Produksi yang diperoleh dalam suatu usaha tani

$\mathrm{P}_{\mathrm{y}}=$ Harga $\mathrm{Y}$

Bila macam tanaman yang diusahakan adalah lebih dari satu maka rumus di atas berubah menjadi .

$$
T R=\sum_{i=1}^{n} Y \cdot P y
$$


Di mana $\mathrm{n}$ adalah jumlah macam tanaman yang diusahakan

Keuntungan atau penerimaan yang diperoleh dari suatu kegiatan usaha pada dasarnya dapat dilihat dari perbandingan jumlah penerimaan dengan total biaya (TR > TC . Pengeluaran total adalah penjumlahan dari semua unsur biaya fixed dan variable cost, dengan persamaan sebagai berikut:

$$
\begin{aligned}
& \mathrm{TC}=\mathrm{FC}+\mathrm{VC} \\
\mathrm{TC} & =\text { Total Cost (Biaya Total) } \\
\mathrm{FC} & =\text { Fixed Cost (Biaya tetap) } \\
\mathrm{VC} & =\text { Variabel Cost (Biaya variabel) }
\end{aligned}
$$

Menurut Soekartawi (2005) dalam menghitung total penerimaan usaha tani perlu dipisahkan : a) Analisis parsial usaha tani dan b) analisis keseluruhan usahatani.

\section{Tenaga Kerja dan Pendapatan Petani}

Menurut Soeroto (2000) tenaga kerja adalah setiap orang mampu melakukan pekerjaan, baik didalam maupun diluar hubungan kerja guna menghasilkan barang atau jasa untuk memenuhi kebutuhan masyarakat. Winardi (2000), mendefinisikan tertaga kerja terbagi 2. Pertama tenaga kerja adalah energi manusia yang dikerahkan kearah tujuan yang ingin dicapai secara. sadar. Kedua, tenaga kerja adalah elemen dari penduduk yang membantu mempertahankan berlangsungnya suatu perekonomian dengan jalan menyediakan suatu kombinasi dari pada energi fisik dan intelegensia manusia kepada proses produktif.

Menurut Volk dalam Artoyo (2001) juga mendefinisikan pekerjaan dalam arti ekonomik. Menurutnya pekerjaan dalam arti ekonomik adalah setiap tindakan dari pikiran dan badan ditujukan untuk mencapai kesenangan dari usaha tersebut.

\section{Metode Penelitian}

Dalam penelitian ini digunakan metode penelitian survei. Menurut Singarimbun (2000) bahwa yang dimaksud dengan penelitian survei adalah penelitian yang menggunakan sampel sebagai pengumpul data pokok.

\section{Karakteristik Responden}

Seperti telah dikemukakan pada sub bab metode penarikan sampel bahwa yang menjadi responden dalam penelitian ini adalah 100 orang petani karet. Karakteristik responden yang terdiri dari komposisi umur, jenis kelamin, status perkawinan, tingkat pendidikan, lamanya bekerja dan pendapatan petani disajikan pada uraian berikut:

\section{Umur}

Tabel 1. Distribusi Frekuensi Petani Karet di Kecamatan Jambi Luar Kota Kabupaten Muaro Jambi Menurut Kelompok Umur 


\begin{tabular}{|c|c|c|}
\hline Umur & Frekuensi & Persentase (\%) \\
\hline $22-26$ & 4 & 4,00 \\
$27-31$ & 19 & 19,00 \\
$32-36$ & 16 & 16,00 \\
$37-41$ & 16 & 16,00 \\
$42-46$ & 17 & 17,00 \\
$47-51$ & 16 & 16,00 \\
$52-56$ & 5 & 5,00 \\
$57-64$ & 7 & 7,00 \\
\hline Jumlah & 100 & 100,00 \\
\hline
\end{tabular}

Sumber : Diolah dari data primer

Dari Tabel di atas terlihat bahwa jumlah responden yang berumur antara 22 26 tahun sebanyak 4 responden atau sebesar 4 persen dari seluruh jumlah responden, responden yang berumur 27 - 31 tahun sebanyak 19 responden atau sebesar 19 persen dari seluruh jumlah responden yang ada.

Responden yang berumur antara 32 - 36 tahun sebanyak 16 responden atau sebesar 16 persen dari seluruh jumlah responden, sementara. responden yang berumur antara 37 - 41 tahun adalah sebanyak 16 responden atau sebesar 16 persen, responden yang berumur antara 42 - 46 tahun sebanyak 17 responden, yang berumur antara 47 - 51 tahun sebanyak 16 responden, yang berumur antara 52 - 56 tahun sebanyak 5 responden dan responden yang berumur 57 - 64 tahun sebanyak 7 responden atau sebesar 7 persen.

\section{Status Perkawinan}

Tabel 2. Jumlah dan Persentase Responden menurut Status perkawinan

\begin{tabular}{|c|c|c|}
\hline Status Perkawinan & Frekuensi & Persentase (\%) \\
\hline Belum Kawin & 6 & 6,00 \\
Kawin & 91 & 91,00 \\
Cerai Hidup & 3 & 3,00 \\
\hline Jumlah & 100 & 100,00 \\
\hline
\end{tabular}

Sumber : Diolah dari data primer

Berdasarkan Tabel di atas dapat dikatakan bahwa sebagian besar responden berstatus kawin, dimana jumlahnya adalah sebanyak 91 responden atau sebesar 91 persen, sedangkan yang berstatus cerai hidup sebanyak 3 orang atau sebesar 3 persen, dan yang berstatus belum kawin jumlahnya relatif kecil yaitu sebanyak 6 orang atau sebesar 6 person.

\section{Jumlah Anggota Keluarga}

Untuk lebih jelasnya jumlah anggota keluarga responden dapat dilihat pada tabel berikut ini:

Tabe13. Frekuensi Responden Dirinci Menurut Jumlah Anggota Keluarga 


\begin{tabular}{|c|c|c|}
\hline $\begin{array}{c}\text { Jumlah Anggota } \\
\text { Keluarga }\end{array}$ & Frekuensi & Persentase (\%) \\
\hline 1 & 3 & 3,00 \\
2 & 18 & 18,00 \\
3 & 30 & 30,00 \\
4 & 22 & 22,00 \\
5 & 9 & 9,00 \\
6 & 8 & 8,00 \\
7 & 1 & 1,00 \\
8 & 3 & 3,00 \\
\hline Jumlah & 100 & 100,00 \\
\hline
\end{tabular}

Sumber : Diolah dari data primer

Berdasarkan tabel di atas tergambar bahwa proporsi responden terbesar adalah mereka yang melniliki anak sebanyak 3 orang, yaitu sebesar 30 responden atau sebesar 30 persen dari jumlah respanden, sementara proporsi terkecil adalah mereka yang memiliki anak sebanyak 7 orang, yaitu sebanyak 1 responden atau sebesar 1 persen.

\section{Tingkat Pendidikan Responden}

Gambaran mengenai keadaan Tingkat pendidikan responden dapat dilihat pada tabel beriku.t ini .

Tabe1 4. Jumlah dan Persentase Responden Menurut Tingkat Pendidikan

\begin{tabular}{|l|c|c|}
\hline Tingkat Pendidikan & Frekuensi & Persentase (\%) \\
\hline Tidak Sekolah & 7 & 7,00 \\
Tamat SD & 78 & 78,00 \\
Tamat SMP & 5 & 8,00 \\
Tamat SMA & 7 & 7,00 \\
D3/S1 & 3 & 3,00 \\
\hline \multicolumn{1}{|c|}{ Jumlah } & 100 & 100,00 \\
\hline
\end{tabular}

Sumber : Diolah dari data primer

Dari Tabel di atas terlihat bahwa secara rata-rata tingkat pendidikan responden masih tergolong sangat rendah. Dimana jumlah penduduk yang tidak tamat SD, tamat SD dan tamat SMP merupakan jumlah terbesar yaitu sebanyak 90 responden, atau sebesar 90 persen. Sebanyak 7 responden atau sebesar 7 persen yang menamatkan pendidikan SMA sederajat dan yang menamatkan pendidikan D3/S. 1 sebanyak 3 responden atau sebesar 3 persen.

\section{Jam Kerja}

Dari jumlah tenaga kerja, tidak semuanya memiliki efektivitas kerja, terutama dikaitkan dengan jam kerja. Semakin tinggi jam kerja maka akan sgmakin efektif pekerjaan yang dihasilkan. Adapun jumlah jam kerja yang digunakan adalah sebagai berikut : 
Tabe1 5. Curahan Jam Kerja efektif

\begin{tabular}{|c|c|c|}
\hline $\begin{array}{c}\text { Tenaga Kerja } \\
\text { (Orang) }\end{array}$ & $\begin{array}{c}\text { Frekuensi } \\
\text { Responden }\end{array}$ & Persentase (\%) \\
\hline $150-5861$ & 65 & 65,00 \\
$562-9763$ & 17 & 17,00 \\
$797-1.385$ & 10 & 10,00 \\
$1.386-1.797$ & 2 & 2,00 \\
$1.798-2.209$ & 3 & 3,00 \\
$2.210-2.621$ & 1 & 1,00 \\
$2.622-3.003$ & 1 & 1,00 \\
$3.0034-3.450$ & 1 & 1,00 \\
\hline Jumlah & 100 & 100,00 \\
\hline
\end{tabular}

Sumber : Diolah dari data primer

\section{Luas Areal Kebun Karet}

Luas areal karet dapat juga dijadikan pedoman besarnya jumlah produksi yang dapat dihasilkan oleh petani. Semakin luas areal kebun karet yang dimiliki oleh seorang petani maka akan semakin besar pula jumlah produksi karet yang dapat dihasilkan, yang pada gilirannya turut berpengaruh kepada pendapatan petani karet itu sendiri.

Untuk lebih jelasnya luas areal karet karet yang dimiliki responden dapat dilihat pada tabel berikut ini :

Tabe1 6. Frekuensi Respanden Dirinci Menurut Luas Areal Kebun Karet yang diusahakan

\begin{tabular}{|c|c|c|}
\hline Ha & Frekuensi & Persentase (\%) \\
\hline $1-5$ & 48 & 48,00 \\
$6-10$ & 36 & 36,00 \\
$11-15$ & 7 & 7,00 \\
$16-20$ & 4 & 4,00 \\
$21-25$ & 3 & 3,00 \\
$26-30$ & 0 & 0 \\
$31-35$ & 1 & 1,00 \\
$36-37$ & 1 & 1,00 \\
\hline Jumlah & 100 & 100,00 \\
\hline
\end{tabular}

Sumber : Diolah dari data primer

Adanya perbedaan dalam penggunaan luas lahan antar petani akan memberikan pengaruh terhadap produksi yang pada gilirannya akan memberikan pengaruh terhadap pendapatan petani. Petani karet yang mengolah lahan lebih luas akan memperoleh pendapatan yang lebih besar pula bila dibandingkan petani yang mengelola lahan yang kecil. Secara rata-rata luas lahan yang dikelola oleh petani karet adalah sebesar 7,48 Ha. Luas lahan yang terluas digunakan petani adalah sebesar $37 \mathrm{Ha}$, sementara Luas lahan terkecil yang diusahakan oleh petani adalah sebesar $1 \mathrm{Ha}$. 


\section{Pengalaman Berusaha Tani}

Pengalaman adalah guru yang paling bermanfaat, demikian kata pepatah, begitu juga dengan pengusahaan lahan perkebunan karet, dengan pengalaman yang dimiliki seorang petani dapat dengan mudah mengatasi permasalahan yang timbul pada waktu mengalami masalah dalam pengelolaan kebun.

Gambaran secara rinci pengalaman berusahan tani dari 100 orang responden dapat dilihat pada tabel berikut ini.

Tabe1 4.7 Pengalaman Berusaha Petani Karet Responden

\begin{tabular}{|c|c|c|}
\hline $\begin{array}{c}\text { Pengalaman Berusaha } \\
\text { Tani (Tahun) }\end{array}$ & Frekuensi & Persentase (\%) \\
\hline $4-5$ & 18 & 18,00 \\
$6-7$ & 11 & 11,00 \\
$8-9$ & 8 & 8,00 \\
$10-11$ & 38 & 38,00 \\
$12-13$ & 0 & 0 \\
$14-15$ & 17 & 17,00 \\
$16-17$ & 0 & 0 \\
$18-20$ & 8 & 800 \\
\hline Jumlah & 100 & 100,00 \\
\hline
\end{tabular}

Sumber : Diolah dari data primer

Berdasarkan tabel di atas tergambar bahwa proporsi responden tertinggi adalah mereka yang memiliki pengalaman berusaha tani antara 10 - 11 tahun, yaitu sebanyak 38 responden atau sebesar 38 persen, sementara proporsi responden terkecil adalah mereka yang memiliki pengalaman berusaha tani karet antara 8 - 9 tahun, yaitu sebanyak 8 responden atau sebesar 8 person. Secara rata-rata pengalaman berusahan tani karet petani karet di Kecamatan Jambi luar Kota Kabupaten Muaro Jambi adalah selama 10,3 tahun.

\section{Pendapatan Petani}

Gambaran secara rinci pendapatan perbulan dari 100 orang responden dapat dilihat pada tabel berikut ini.

Tabe1 8. PendapatanTotal Petani Karet Responden

\begin{tabular}{|c|c|c|}
\hline $\begin{array}{c}\text { Kelas Pendapatan } \\
\text { (Rupiah)/bulan }\end{array}$ & Frekuensi & Persentase (\%) \\
\hline $841.000-4.975 .499$ & 45 & 45,00 \\
$4.975 .500-9.109 .999$ & 37 & 37,00 \\
$9.110 .000-13.244 .499$ & 7 & 7,00 \\
$13.244 .500-17.378 .999$ & 6 & 6,00 \\
$17.379 .000-21.513 .499$ & 2 & 20,00 \\
$21.513 .500-25.647 .99$ & 1 & 1,00 \\
$25.648 .000-29.782 .499$ & 0 & 0,00 \\
$29.782 .500-33.917 .000$ & 2 & 2,00 \\
\hline Jumlah & 100 & 100,00 \\
\hline
\end{tabular}


Sumber : Diolah dari data primer

Jumlah responden tertinggi pada kelompok pendapatan antara Rp. 841.000 4.975.499, yaitu sebanyak 45 responden atau sebesar 45 persen, sementara jumlah responden terendah berada pada kelompok pendapatan antara Rp. 21.513.500 25.647.999 perbulan, yaitu sebanyak 1 responden atau sebesar 1 persen. Penerimaan rata-rata 100 orang responden petani rata-rata adalah sebesar Rp. 6.973.085.

Bila rata-rata jumlah anggota keluarga yang menjadi tanggungan responden diasumsikan sebanyak 4 orang maka pendapatan perkapita responden adalah sebesar Rp. 1.1621.803 perbulan.

\section{Hasil Regresi}

\section{A. Persamaan Regresi}

Dari hasil pengujian model pertama regresi linear berganda (Lampiran 4) menghasilkan persamaan regresi berganda sebagai berikut :

Coefficients $^{\mathrm{a}}$

\begin{tabular}{|l|r|r|r|r|r|}
\hline \multirow{2}{*}{ Model } & \multicolumn{2}{|c|}{$\begin{array}{c}\text { Unstandardized } \\
\text { Coefficien }\end{array}$} & $\begin{array}{c}\text { Stadnardized } \\
\text { Coefficeien }\end{array}$ & \multirow{2}{*}{$\mathrm{t}$} & \multirow{2}{*}{ Sig. } \\
\cline { 2 - 4 } & \multicolumn{1}{|c|}{ B } & Std. Error & \multicolumn{1}{c|}{ Beta } & & \\
\hline 1. (Constan) & 5.908 & .118 & & 49.967 & .000 \\
X1 & .039 & .004 & .041 & 9.750 & .000 \\
X2 & .961 & .066 & .930 & 14.593 & .000 \\
X3 & .037 & .013 & .026 & 2.847 & .003 \\
X4 & .067 & .028 & .058 & 2.448 & .016 \\
\hline
\end{tabular}

Tabel di atas maka dapat disusun model persarnaan regresi Berganda sebagai berikut $Y=5,908+0,039 X_{1}+0,961 X_{2}+0,037 X_{3}+0,067 X_{4}$

Berdasarkan hasil pengujian model regresi di atas tergambar bahwa setiap terjadi penambahan jam kerja efektif sebesar 1 persen maka pendapatan petani karet di Kecamatan Jambi Luar Kota Kabupaten Muaro Jambi akan mengalami penningkatan sebesar 0,039. Di sisi lain setiap terjadi peningkatan luas lahan kebun karet sebesar 1 persen maka pendapatan petani karet di Kiecamatan Jambi luar Kota Kabupaten Muaro Jambi akan mengaiami peningkatan sebesar 0,961 persen. Sementara apabila pengalaman berusaha tani karet semakin bertambah maka pendapatan petani karet di Kecamatan Jambi Luar Kota Kabupaten Muaro Jambi akan mengalami peningkatan sebesar 0,037 persen dan setiap terjadi penambahan pendidikan formal sebesar 1 persen maka pendapatan petani karet di Kecamatan Jambi luar Kota Kabupaten Muaro Jambi akan mengalami peningkatan sebesar 0,067 persen. 


\section{B. Pengujian Signifikan}

\section{Pengujian Secara Simultan (Uji F)}

Uji F dipergunakan untuk melihat apakah secara bersama-sama. variabel Xi (jam kerja efektif, luas lahan, pengalaman berusaha tani dan tingkat pendidikan) yang dimasukkan dalam model berpengaruh secara signifikan terhadap pendapatan petani karet di Kecamatan Jambi Luar Kota Kabupaten Muaro Jambi.

Dari hasil pengujian diperoleh nilai F hitung sebesar 438,740 Dengan tingkat keyakinan sebesar 95 persen $\alpha=0,05 \mathrm{df}=(96)$ (6) diperoleh nilai $\mathrm{F}$ tabel sebesar 2,53 . Dengan demikian nilai F hitung $(29831,659)$ lebih besar dari nilai $F$ tabel $(2,53)$. Artinya secara bersama-sama (jam kerja efektif, Luas lahan, pengalaman berusaha taru dan tingkat pendidikan) memiliki pengaruh secara signifikan terhadap pendapatan petani karet di Kecamatan Jambi Luar Kota Kabupaten Muaro Jambi.

\section{Pengujian Secara Partial}

Uji $\mathrm{t}$ dipergunakan untuk melihat apakah secara parsial masing-masing variabel independent (jam kerja efektif, Luas lahan, pengalaman berusaha tani dan tingkat pendidikan) yang diteliti berpengaruh secara. signifikan terhadap pendapatan petani karet di Kecamatan Jambi Luar Kota Kabupaten Muara Jambi

Dari hasil pengujian diperoleh nilai t hitung untuk variabel Jam Kerja adalah sebesar 9,750 sementara nilai t tabel dengan tingkat keyakinan 95\% diperoleh angka sebesar 1,67. Hal ini berarti bahwa nilai t hitung $(9,750)$ lebih besar dari mlai t tabel yang mengandung arti bahwa Ho ditolak artinya terdapat pengaruh yang signifikan antara jam kerja efektif dengan pendapatan petani karet di Kecamatan Jambi Luar Kota Kabupaten Muaro Jambi Nilai t hitung untuk variabel Luas lahan diperoleh sebesar 14,593. sementara nilai t tabel dengan tingkat keyakinan 95\% diperoleh sebesar 1,67. Hal ini berarti nilai t hitung $(14,593)$ lebih besar dari nilai t tabel $(1,67)$ yang berarti Ho ditolak artinya terdapat pengaruh yang signifikan antara jam kerja efektif dengan pendapatan petani karet di Kecamatan Jambi Luar Kota Kabupaten Muaro Jambi.

Di sisi lain nilai t hitung untuk variabel pengalaman berusaha tani petani karet diperoleh sebesar 2,847 sementara nilai t tabel pada tingkat keyakinan sebesar 95 persen diperoleh sebesar 1,67 , hal ini berarti nilai t hitung $(2,847)$ lcbih besar dari nilai t tabel $(1,67)$. Dengan demikian maka Ho ditolak dengan kata lain pengalaman berusaha tani karet berpengaruh secara. signifikan terhadap pendapatan petani karet di Kecamatan Jambi Luar Kota Kabupatgn Muaro Janbi.

Nilai t hitung untuk tingkat pendidikan petani karet adalah sebesar 2,448, sementara nilai t tabel pada tingkat keyakinan sebesar 95 persen diperoleh sebesar 1,67 , hal ini berarti nilai t hitung $(2,847)$ lebih besar dari nilai t tabel $(1,67)$. Dengan 
demikian maka Ho ditolak dengan kata lain tingkat pendidikan petani karet berpengaruh secara signifikan terhadap pendapatan petani karet di Kecamatan Jambi Luar Kota Kabupaten Muaro Jambi.

\section{Pengujian Koefisien Determinasi dan Korelasi}

Koefisien determinasi dipergunakan untuk melihat berapa besar variabel $\mathrm{Xi}$ (jam kerja efektif, luas lahan, pengalaman berusaha tani dan tingkat pendidikan) dapat menjelaskan variasi naik turunnya pendapatan petani karet Dari hasil pengujian sebagaimana pada lampiran 4 diperoleh nilai koefsien determinasi sebesar 0,949. Hal ini memberikan gambaran bahwa 94,9 persen variasi naik turunnya pendapatan petani karet di Kecamatan Jambi Luar Kota Kabupaten Muaro Jambi dijelaskan oleh jam kerja efektit Luas lahan, pengalaman berusaha tani dan tingkat pendidikan.

Koefsien korelasi diperoleh sebesar 0,974. Nilai ini mendekati angka 1 yang berarti terdapat hubungan yang sangat kuat antara variabel jam kerja efektif, luas lahan, pengalaman berusaha tani dan tingkat pendidikan dengan pendapatan petani karet di Kecamatan Jambi Luar Kota Kabupaten Muaro Jambi.

\section{Kesimpulan}

Dari hasil penelitian dan pembahasan ada beberapa hal yang dapat disimpulkan, yaitu :

1. Secara rata-rata umur responden adalah 40,25 tahun, jumlah anak pada keluarga petani karet adalah sebanyak 4 orang. Di sisi lain secara rata-rata pengalaman berusaha tani responden adalah selama 10,31 tahun. Secara rata-rata jam kerja efektif yang digunakan oleh resonden adalah sebesar 633,75 jam perbulan. Luas lahan ratarata yang digunakan petani adalah $7,48 \mathrm{Ha}$ dan pendapatan rata-rata 100 orang responden petani rata-rata adalah sebesar Rp. 6.973.085.

2. Setiap terjadi penambahan jam kerja efektif sebesar 1 persen maka pendapatan petani karet di Kecamatan Jambi Luar Kota Kabupaten Muaro Jambi akan mengalami peningkatan sebesar 0,039. Di sisi lain setiap terjadi peningkatan luas lahan kebun karet sebesar 1 persen maka pendapatan petani karet di Kecamatan Jambi luar Kota Kabupaten Muaro Jambi akan mengalami peningkatan sebesar 0,961 persen.

\section{Saran-saran}

Mengingat variabel yang dominan mempengaruhi pendapatan petani karet di Kecamatan Jambi Luar Kota Kabupaten Muaro Jambi adalah curahan jam kerja, Luas lahan, pengalaman berusaha tani dan tingkat pendidikan maka ada beberapa saran yang dapat diberikan, yaitu :

1. Pemerintah diharapkan lebih berupaya dalam mendorong peningkatan kualitas petani melalui berbagai pelatihan dan penyuluhan, hal ini sangat penting guna mengembangkan pola pikir Petani. 
2. Petani secara efisien hendaknya memanfaatkan tenaga kerja dengan mengoptimalkan waktu kerja petani secara maksimal, agar diperoleh produktivitas yang tinggi.

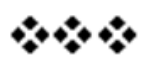

\section{DAFTAR PUSTAKA}

Anonim, 1998, Info Kuantitatif Jambi 42 Tahun Provinsi Jambi, Jambi, ,2009, Proyeksi Sub Sektor Perkebunan Tahun 1999-2009, Jambi. , 2005, Laporan Tahunan Dinas Perkebunan Provinsi Jambi Tahun 2004, Jambi

Arsyad, Lincolin, 2001, Pengantar Ekonomi Pembanaunan, YKPN, Yogyakarta

Assauri, Sopyan, 2001, Teori Produksi, LP FE-UI, Jakarta

Bambang,2009, Pengembangan Ago Bisnis, Jurnal, Departemen Pertanian Bilas, Richard A, 2004, Teori Ekonomi Mikro, Rineka Cipta, Jakarta

Desmaliza, 2001, Kontribusi Sub Sektor Perkebunan Terhadap PDRB Sektor Pertanian Provinsi Jambi, Skripsi (tidak dipublikasikan)

Dillon, HS, 2009, Kebijakan Pembangunan Peatanian di Indonesia Sinar Grafika, Jakarta

Djoyohdikusumo Soemitro, 2004, Ekonomi Pembangunan, PT. Pembangunan, Jakarta.

Dumairy, 2000, Perekonomian Indonesia, Erlangga, Jakarta

Elfindri dan Nasir Bachtiar, 2002, Ekonomi Ketenagakerjaan, Andalas University Press, Padang

Hernanto, Fadoli, 2040, Usaha Tani, Sunar Tani, Jakarta

Kuncoro, Mudrajad, 2000, Ekonomi Pembangunan, YKPN, Yogyakarta

Lipsey, G. 2001, Pengantar Ekonomi, Terjemahan Erlangga, Penerbit PT. Erlangga Jakarta

Mubyarto, 2000, Pengantar Ekonomi Pertanian, Edisi 6, LP3ES, Jakarta

Mulyanto dan Ever, 2002, Ekonomi Pertanian Sinar Tani Jakarta Partadiredja, Ace, 2000, Ekonomika, UI Press, Jakarta 